\title{
FOXR1 wt Allele
}

National Cancer Institute

\section{Source}

National Cancer Institute. FOXR1 wt Allele. NCI Thesaurus. Code C143125.

Human FOXR1 wild-type allele is located in the vicinity of $11 \mathrm{q} 23.3$ and is approximately 10

$\mathrm{kb}$ in length. This allele, which encodes forkhead box protein $\mathrm{R} 1$, is involved in the

modulation of gene transcription. 